https://doi.org/10.11646/zootaxa.0000.0.0

http://zoobank.org/urn:lsid:zoobank.org:pub:00000000-0000-0000-0000-00000000000

\title{
Re-evaluation of the taxonomic status of Vegaranina (Crustacea: Raninidae) from the Late Cretaceous of Cuba, with description of a new species
}

\author{
ALBERTO ARANO-RUIZ1 ${ }^{1}$, LAZARO W. VIÑOLA-LÓPEZ ${ }^{2,4}$, \\ REINALDO ROJAS-CONSUEGRA ${ }^{3}$ \& CARLOS RAFAEL BORGES-SELLEN ${ }^{1}$ \\ ${ }^{I}$ Sociedad Cubana de Geología, Cienfuegos, Cuba \\ ${ }^{2}$ Department of Earth Sciences, Montana State University, Bozeman, MT, 59717, USA \\ ${ }^{3}$ Instituto de Investigaciones del Petróleo, La Habana, Cuba \\ ${ }^{4}$ Corresponding author.E-mail: lwvl94@gmail.com
}

\begin{abstract}
A new species of raninid crustacean, Vegaranina rivasi sp. nov, is described based on three specimens collected from a Late Cretaceous deposit in central Cuba. Previous studies assigned one of the specimens to Vegaranina precocia (Feldmann, Vega, Tucker, Garcia-Barrera \& Avendano, 1996), a species described from the Late Cretaceous of Mexico. However, after collecting the new specimens and recent major revisions of the group, we identified a unique combination of characters in the Cuban specimens that separate them from the other species in the genus.
\end{abstract}

Key words: Fossil, Vegaranina rivasi sp. nov, Campanian-Lower Maastrichtian

\section{Resumen}

Se describe una nueva especie de crustáceo ranínido, Vegaranina rivasi sp. nov, basados en tres ejemplares colectados en un depósito de edad Cretácico Tardío en el centro de Cuba. En previos estudios uno de los ejemplares fue asignado a Vegaranina precocia (Feldmann, Vega, Tucker, Garcia-Barrera \& Avendano, 1996) especie descrita para Cretácico Tardío de México. Sin embargo, el descubrimiento de nuevos ejemplares junto a recientes revisiones del grupo nos permitió identificar en los ejemplares cubanos una combinación única de caracteres que la separan de la otra especie del género.

Palabras claves: Fossil, Vegaranina rivasi sp. nov, Campaniano-Maastrichtiano Inferior

\section{Introduction}

Varela \& Rojas-Consuegra (2009) reported for the first time the carapace of an extinct raninid crustacean which they identified as Lophoranina precocious Feldmann, Vega, Tucker, Garcia-Barrera \& Avendano, 1996, from Late Cretaceous rocks of central Cuba. This species was previously only known from deposits of similar age in Mexico and Puerto Rico (Feldmann et al. 1996; Schweitzer et al. 2007). More recently, Van Bakel et al. (2012) erected the genus Vegaranina to host this species based on several synapomorphies, separating V. precocia from the EoceneMiocene Lophoranina Fabiani, 1910 (Van Bakel et al. 2012, Karasawa et al. 2014). At the same time, Van Bakel et al. (2012) mentioned the existence of two other undescribed species of Vegaranina, one from southern France and the other from an unknown locality.

Meanwhile, two additional specimens of Vegaranina were collected from the locality in Cuba where the genus was previously reported (Varela \& Rojas-Consuegra 2009). The revision of the new fossils and the specimen previously reported by Varela \& Rojas-Consuegra (2009), showed the presence of characters that separate the Cuban specimens from V. precocia (Feldmann et al. 1996; Van Bakel et al. 2012; Karasawa et al. 2014). The new species Vegaranina rivasi sp. nov. differs from $V$. precocia in its greater level of terrace fusion and serrated 
margins in the carapace. The description of the new species from Cuba has implications for the taxonomic status of the Puerto Rican specimen previously identified as Lophoranina cf. precocious (Schweitzer et al. 2008)

The following abbreviations were used: br, branchial region; cr, cardiac region; eb, epibranchial region; in, inner orbital spine; it, intra-orbital spine; msg, mesogastric region; mtg, metagastric region; oo, outer orbital spine; ro, rostrum; s1-3: anterolateral spines; T1-T7: transversal terraces.

\begin{tabular}{|c|c|c|c|c|}
\hline$\stackrel{8}{8}$ & '气 & 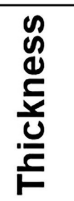 & Lithology & Composition \\
\hline 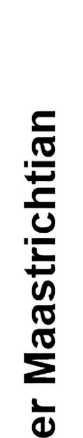 & 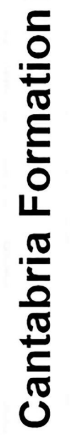 & $\begin{array}{l}E \\
\stackrel{E}{O} \\
\stackrel{2}{2}\end{array}$ & 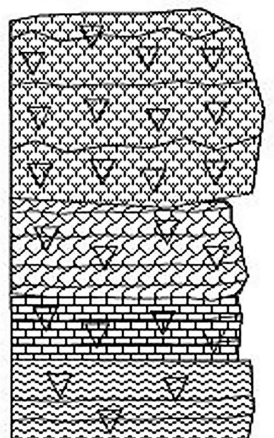 & $\begin{array}{l}\text { Biogenic and bioclastic limestone of coarse grain, } \\
\text { massive to irregularly stratified. } \\
\text { Biodetritic limestone of medium to fine grain, } \\
\text { and loam with irregular stratification } \\
\text { Micritic limestone, recrystallised }\end{array}$ \\
\hline 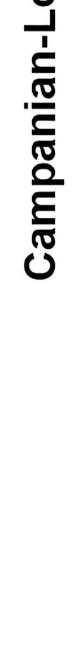 & 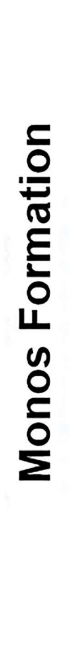 & $\begin{array}{l}E \\
\text { 용 }\end{array}$ & 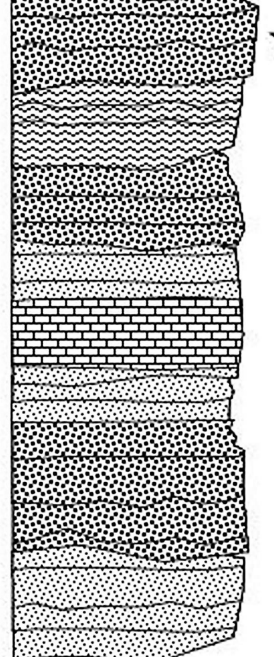 & $\begin{array}{l}\text { Polymictic sandstone } \\
\text { Marl and siltstone } \\
\text { Sandstone of, coarse grain to calcarean grab } \\
\text { Sandy limestone of medium to coarse grain, massive } \\
\text { Fragmented limestone }\end{array}$ \\
\hline
\end{tabular}

FIGURE 1. Stratigraphic section of Monos Formation in the region where the specimens of Vegaranina rivasi sp. nov. were collected.

Systematic paleontology

Order DECAPODA Latreille, 1803

Family RANINIDAE De Haan, 1839

Subfamily Ranininae De Haan, 1839

Vegaranina Van Bakel, Guinot, Artal, Fraaije \& Jagt, 2012

Type species. Lophoranina precocious Feldmann, Vega, Tucker, Garcia-Barrera and Avendano, 1996.

Included species. Vegaranina sp. 1 (Van Bakel et al. 2012: 95), Vegaranina sp. 2 (Van Bakel et al. 2012: 95), 
Vegaranina rivasi, sp. nov.

Range. Early Maastrichtian (Late Cretaceous), Chiapas, Mexico; Maastrichtian Puerto Rico; CampanianLower Maastrichtian, Cienfuegos, Cuba; Maastrichtian, southern France.

Diagnosis. See Van Bakel et al. (2012)

\section{Vegaranina rivasi sp. nov.}

(Figs. 2-4)

Lophoranina precocious, Varela \& Rojas-Consuegra 2009: 118, 119, 122; Varela \& Rojas-Consuegra 2011: 3, 6; Van Bakel et al. 2012: 95; Luque et al. 2017: 56. [Not L. precocious Feldmann, Vega, Tucker, Garcia-Barrera \& Avendano, 1996]

Material examined. The holotype (MMC-5-68-1) is an almost complete carapace, preserving all the terraces, anterolateral spines, extraorbital tooth and part of the tridentate rostrum. The specimen has a diagonal fracture from the right margin of the $4^{\text {th }}$ terrace to the midline of the branchiocardiac groove. The paratypes (MMC-5-68-2, 5-683 ) are right and left half of the carapaces of two specimens partially preserving some of the terraces. The specimen MMC-5-68-1 was collected in 1999 by Luis Orlando, and the paratypes were collected by Jesús Servilio Quintero in 2014. All specimens are deposited at the Museo Municipal de Cruces (MMC).

Measurements (in mm): Holotype MMC-5-68-1 length: 90, width: 75; paratype MMC-5-68-2 length (estimated) 50, width (estimated) 40.

Type locality. The holotype (MMC-5-68-1) was collected about $1.5 \mathrm{~km}$ south of the town Potrerillo, while the paratypes (MMC-5-68-2, 5-68-3) at $1 \mathrm{~km}$ east of the same town, in the Municipality of Cruces, Cienfuegos Province, Cuba.

Geologic formation and age. Recent investigations of the area of provenance of the specimens indicates that those rocks belong to the Monos Formation (Truitt, P., in Brönnimann \& Pardo 1954) and not the Cotorro Formation as was initially suggested by Varela \& Rojas-Consuegra (2009). The Monos Formation represents a transgressive cycle characterized by a sequence of polymictic gravels that transgress into sandstones, formed by the erosion of the Antillean Cretaceous Volcanic Arc (Fig. 1). Limonites, and loam can also be found intercalated in some sections of the outcrop. These rocks were deposited during the Campanian - Lower Maastrichtian in a shallow marine environment with strong input of terrestrial sediments that was decreasing over time as the transgression progressed (IGP, 2013). The three specimens were found in sandstone nodules weathered out from the structural rock. Several ammonites, gastropods, bivalves, echinoderms and wood fragments have also been collected from the same sandstone section. In the region, the Monos Formation is transitionally covered by Maastrichtian carbonates of the Cantabria Formation (Truitt, P., in Brönnimann \& Pardo 1954; Kantshev et al. 1976).

Etymology. The species is named in memory of Danilo Rivas Enterrio (1962-2014) who was an important collector of fossils from Cienfuegos, Cuba.

Diagnosis. Species of Vegaranina, with the following unique combination of characters: large anterolateral spines (larger than post-orbital spine), lateral and posterolateral margin with small spines. First and second transverse terraces plus mesogastric, metagastric, and cardiac region fused at carapace midline (Fig. 2, 3); interrupting cervical, cardiac and branchiocardiac grooves. Anterior and posterior terraces of branchial region partially fused.

Description. Large, wide raninid, with ovoid carapace, convex transversely, reaching its maximum width at level of middle epibranchial terrace. Carapace converging strongly towards the posterior region, from fourth transverse terrace posterior to the cardiac region. Lateral and post-lateral margin of the carapace serrated with small spines (Fig. 4), similar to serration on terraces. Carapace divided into three main anteroposterior sections: rostrum and post-frontal region; lobulated terraces between the postfrontal region and branchiocardiac groove; seven transverse terraces from side to side posterior to branchiocardiac grooves. Tridentate rostrum not completely preserved, axial spines serve as inner orbital spines, right lateral spine from the rostrum preserved. Orbits wide and concave, with two large and open fissures; inner one placed between inner orbital spine and blunt intra-orbital spine. Outer fissure located between blunt intra-orbital spine and outer orbital spine, which is directed anteriorly. Anterolateral margin bears three prominent and flattened spines, longer than wide, larger than post-orbital spine, directed anterolaterally and anteriorly depending on the spine. Post-frontal region broad and non-terraced. 
Lobulated terraces separated from the post-frontal region by cervical grove, and from the seven main transverse terraces by branchiocardiac. Lobulated terraces and the ones located posterior the branchiocardiac groove, are serrated on the anterior ridge and gently inclined backward. Epibranchial region with three serrated terraces. Epibranchial region separated from branchial and metagastric region by a diagonal groove. Branchial region composed of two terraces nearly completely fused, anterior terrace near five times smaller than posterior terrace. Branchial region separated from cardiac and metagastric region by diagonal groove. Mesogastric, metagastric and cardiac region plus first and second transverse terraces fused on the midline by a stripe $5 \mathrm{~mm}$ wide. Fusion of previous mentioned structures interrupt the cervical, cardiac, and branchiocardiac grooves. Cardiac lobes appear to be rhomboidal and not serrated. Region posterior to branchiocardiac groove and composed by metabranchial, mesobranchial, and intestinal region are undifferentiated; cut by seven strong serrated terraces transverse from side to side. Terraces are concave and resembles a wide U. Other terraces show lower level of fusion or connection, varying among individuals.

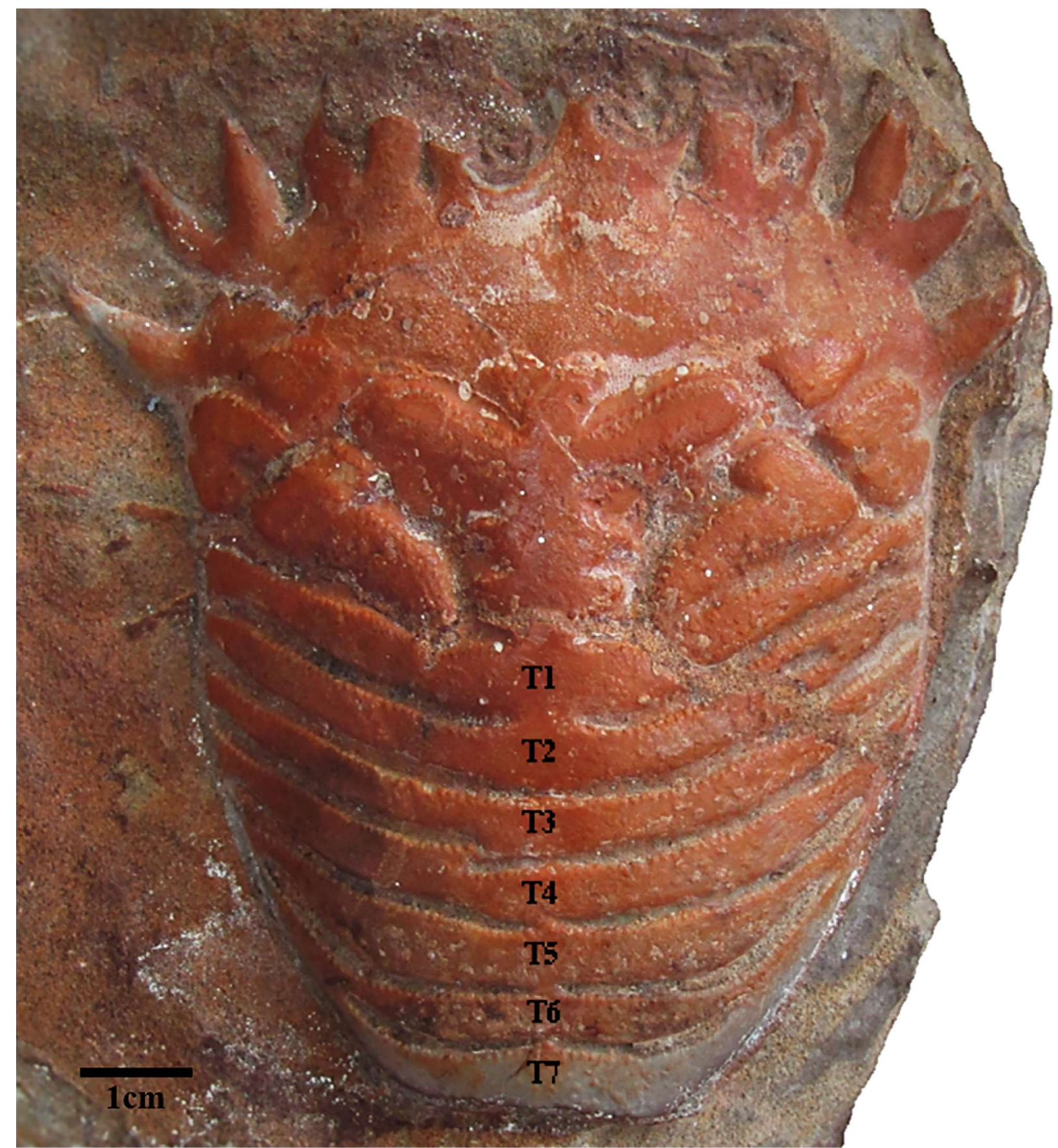

FIGURE 2. Dorsal view of the nearly complete carapace of the holotype of $V$. rivasi sp. nov. MMC-5-68-1. T1-T7 refers to the order of the transversal terraces. 


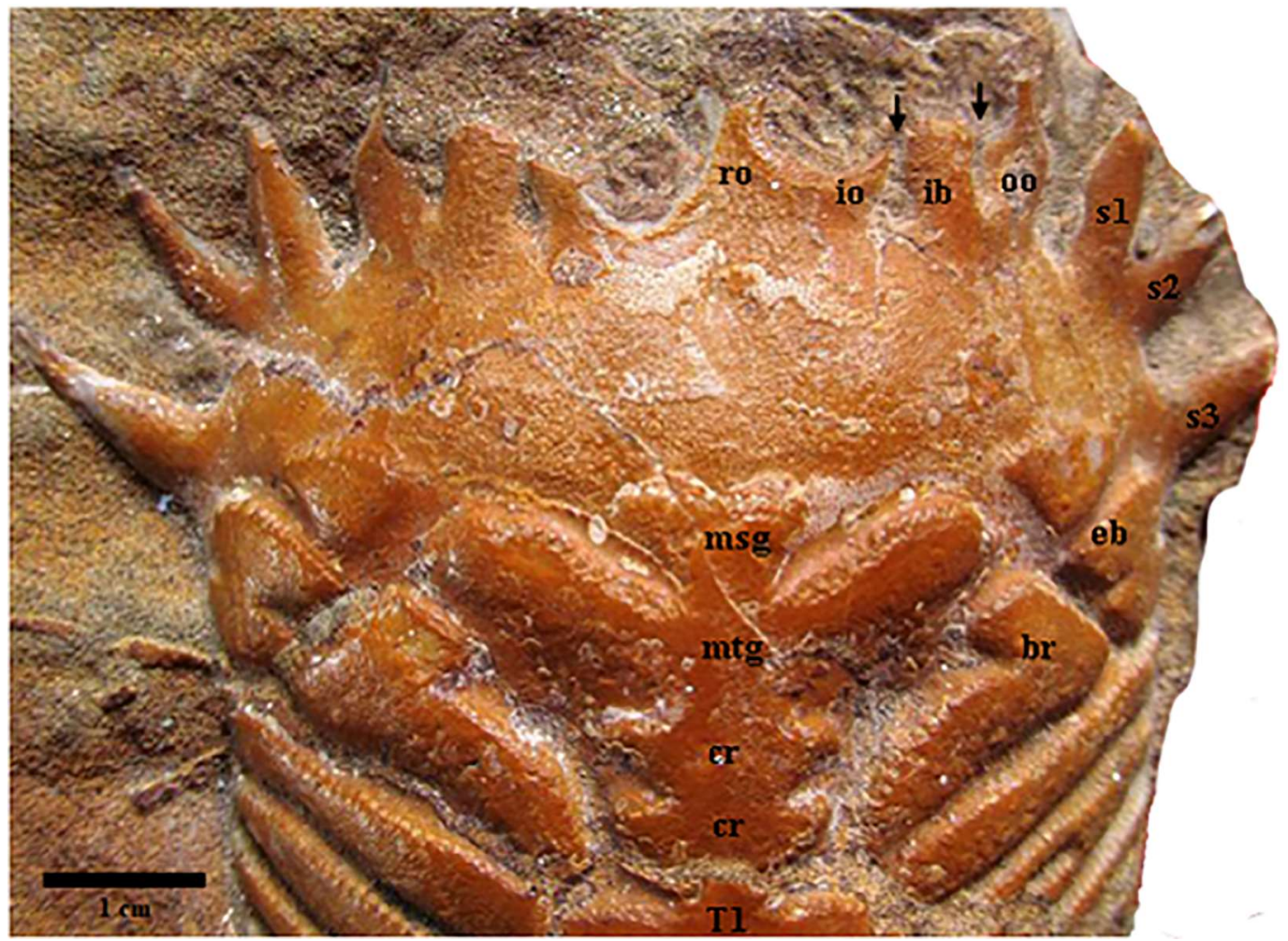

FIGURE 3. Anterior half of the holotype of $V$. rivasi sp. nov. with some of the most important structures. Notice the fusion between the mesogastric (msg), metagastrial $(\mathrm{mtg})$ and cardiac region ( $\mathrm{cr}$ ). The two arrows indicate the presence of the open orbital fissures.

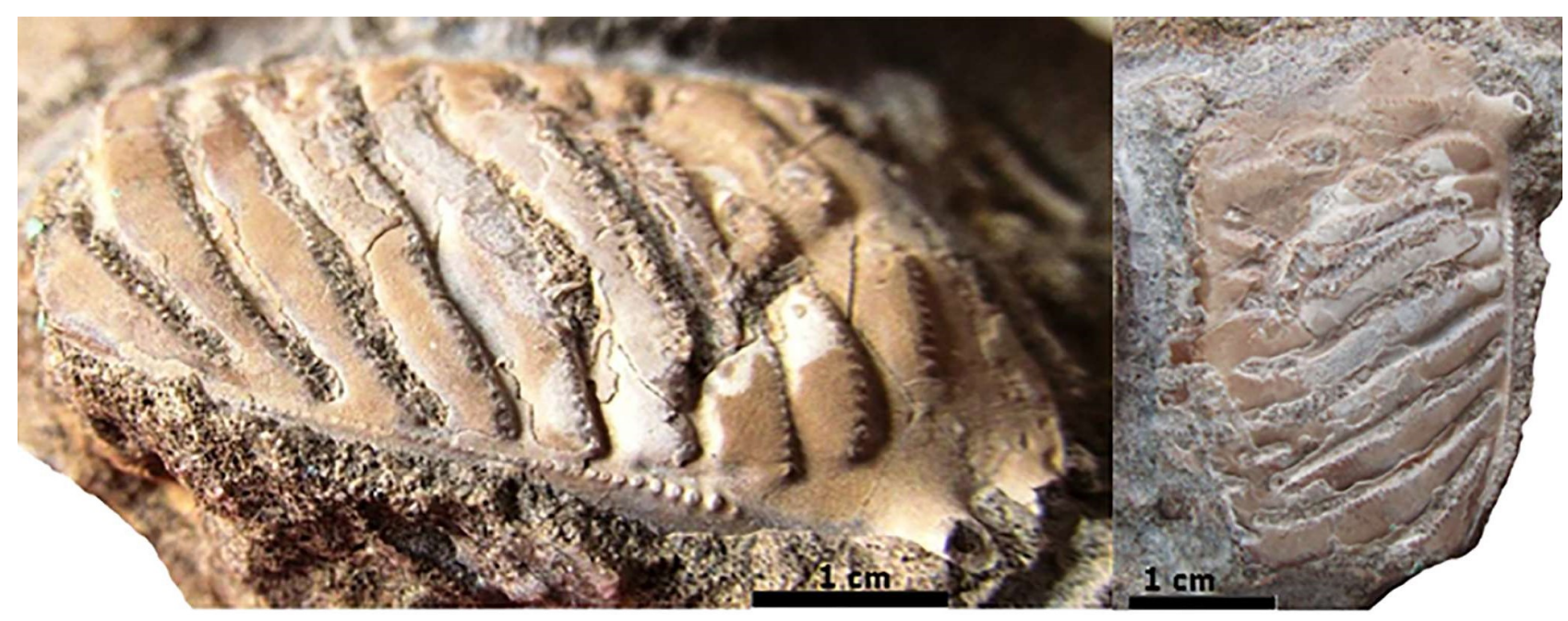

FIGURE 4. Lateral and dorsal view of the partial carapace of the paratype of $V$. rivasi sp. nov. MMC-5-68-2. Notice the lateral spines on the margin of the specimen.

Remarks. The genus Vegaranina was erected by Van Bakel et al. (2012) to contain Lophoranina precocious and two undescribed species. Vegaranina rivasi sp. nov, differs from $V$. precocia by the fusion of the mesogastric, metagastric and cardiac region as well as the first and second transverse terraces on the midline by a stripe of 5 $\mathrm{mm}$. In $V$. precocia, each of these structures is separated by deep grooves. The lateral margins of the carapace of $V$. rivasi sp. nov are serrated, but these are smooth in $V$. precocial. The three anterolateral spines are larger in $V$. rivasi sp. nov., although Feldmann, and Schweitzer (2007) observed that the length of the spines could vary because of sexual dimorphism. Among the lobulated terraces, the cardiac terraces of $V$. rivasi $\mathbf{s p . ~ n o v . ~ a r e ~ s u b r h o m b o i d a l , ~}$ while in $V$. precocia they tend to be rectangular. The differences observed between the specimens from Cuba and Mexico cannot be explained by ontogenetic changes because the characters that distinguish the species are stable in 
individuals of distinct size in each taxon (Feldmann et al. 1996, Vega et al. 2018); also, the size of the paratypes of the Cuban species (MMC-5-68-2, 5-68-3) overlap with the size of V. precocia. Although the sex of the specimens from both species has not been determined, it seems unlikely that the seven fossil specimens of $V$. precocia reported by Vega et al. (2018) represent one sex and the three Cuban specimens the other. We consider that with the exception of the differences in spine size, sexual dimorphism fails to be the cause of the difference between other characters. Lastly, Klompmaker et al. (2015) demonstrated that the differential preservation of the cuticle in fossil decapod crustaceans can have important effects for species identification. Nevertheless, in all specimens of $V$. rivasi sp. nov., and in the holotype (Feldmann et al. 1996, fig. 3) and neotype of $V$. precocia, (Vega et al 2018, fig. 6) the cuticle is preserved.

Schweitzer et al. (2008) reported Lophoranina cf. precocious from the Late Cretaceous of Puerto Rico. However, the specimen lacks most of the region anterior to the branchiocardiac groove, and the characters that differentiate $V$. precocia and $V$. rivasi sp. nov. cannot be evaluated. We recommend to referring the Puerto Rican specimen to Vegaranina sp. until more and better preserved specimens are found.

Feldmann et al. (1996) proposed that the presence of fewer and stronger terraces in V. precocia (L. precocious) is a primitive character that evolved later in numerous, and thinner terraces in the Eocene-Miocene Lophoranina. Van Bakel et al. (2012) stated that Vegaranina could be the link between the Cenomanian Lophoraninella cretacea (Dames, 1886) and Eocene-Miocene Lophoranina. Nonetheless, L. cretacea is characterized by two anterolateral spines and several thin terraces (Van Bakel et al. 2012), like Lophoranina (Karasawa et al. 2014), and it seems unlikely that in the transitional form (Vegaranina) these key characters would be different. Posteriorly, Karasawa et al. (2014) in a phylogenetic study of Raninoida found that Lophoranina and Vegaranina are sister genera, linked by the character of carapaces with terrace ornamentation. Nevertheless, Lophoraninella cretacea was not included in the phylogeny by Karasawa et al. (2014), because the type specimens are poorly preserved. It seems that until better specimens of Lophoraninella are found, its phylogenetic position in respect to Lophoranina and Vegaranina remains unclear.

The distribution pattern of Vegaranina spp. in America and Europe during the late Cretaceous support the hypothesis that the genus originated in the Tethys region (Feldmann et al. 1996, Schweitzer et al. 2007). It also indicates that the genus was widely dispersed, with at least 3 species living throughout the Tethys (Van Bakel et al. 2012, Vega et al. 2018).

\section{Acknowledgements}

We want to thank to Johanset Orihuela, Richard Carr, and Carlos Varela for the critical review of the manuscript. Our deepest gratitude to the editor Jose Christopher Escano Mendoza and the reviewer Barry van Bakel for all the comments and recommendations during the revision. Also, we are grateful to Luis Orlando and Jesús Servilio Quintero, collectors of the specimens described here.

\section{References}

Feldmann, R.M. \& Schweitzer, C.E. (2007) Sexual dimorphism in extinct and extant Raninidae (Decapoda: Brachyura). Annals of Carnegie Museum, 76 (1), 39-52. https://doi.org/10.2992/0097-4463(2007)76[39:SDIEAE]2.0.CO;2

Feldmann, R.M., Vega, F., Tucker, A.B., Garcia-Barrera, P. \& Avendano, J. (1996) The oldest record of Lophoranina (Decapoda: Raninidae) from the late Cretaceous of Chiapas, southeastern Mexico. Journal of Paleontology, 70 (2), 296-303. https://doi.org/10.1017/S0022336000023386

Gil-Gonsalez, S. (2013) Subcomscion del Cretacico. InLexico estratigráfico de Cuba. : Instituto de Geologia y Paleontologia, La Habana, 458 pp.

Luque, J., Schweitzer, C. E., Santana, W., Portell, R.W., Vega, F.J. \& Klompmaker, A.A. (2017) Checklist of fossil decapod crustaceans from tropical America. Part I: Anomura and Brachyura. Nauplius, 25, e2017025.

Kantshev, I., Boyanov, I., Goranov, A., Iolkichev, N., Cabrera, R., Kanazirski, M., Popov, N. \& Stanchea, M. (1976) Geología de la provincia de Las Villas. Resultados de las investigaciones geológicas y levantamiento geológico a escala 1:250 000, realizado durante el periodo 1969-1975. Brigada CubanoBúlgara, Instituto de Geologia y Paleontologia, Academia de 
Ciencias de Cuba, La Habana. [unkown pagination, inédito]

Karasawa, H., Schweitzer, C.E., Feldmann, R.M. \& Luque, J. (2014) Phylogeny and classification of Raninoida (Decapoda: Brachyura). Journal of Crustacean Biology, 34 (2), 216-272.

https://doi.org/10.1163/1937240X-00002216

Klompmaker, A.A., Hyžný, M. \& Jakobsen, S.L. (2015) Taphonomy of decapod crustacean cuticle and its effect on the appearance as exemplified by new and known taxa from the Cretaceous-Danian crab Caloxanthus. Cretaceous Research, $55,141-151$. https://doi.org/10.1016/j.cretres.2014.11.011

Schweitzer, C.E., Velez-Juarbe, J., Martinez, M., Hull, A.C., Feldmann, R.M. \& Santos, H. (2008) New Cretaceous and Cenozoic Decapoda (Crustacea: Thalassinidea, Brachyura) from Puerto Rico, United States Territory. Bulletin of the Mizunami Fossil Museum, 34 (1), 1.

Truitt, P. (1954) Annotations to the correlation chart and catalogue of formations (Las Villas province). In: Brönnimann, P. \& Pardo, G. (Eds.), Reporte geologico 456. Centro Nacional Fondo Geologico., Ministerio de Industria Basica, La Habana. [unkown pagination, inédito]

Van Bakel, B.W.M., Guinot, D., Artal, P., Fraaije, R.H.B. \& Jagt, J.W.M. (2012) A revision of the Palaeocorystoidea and the phylogeny of raninoidian crabs (Crustacea, Decapoda, Brachyura, Podotremata). Zootaxa, 3215, 1-216.

Varela, C. \& Rojas-Consuegra, R. (2009) Crustaceos (Decapoda: Brachyura) fosiles de Cuba. Solenodon, 8, 118-123.

Varela, C. \& Rojas-Consuegra, R. (2011) El registro fosil de los crustaceos decapodos (Arthropoda, Crustacea) marinos de Cuba. IX Congreso Cubano de Geologia, Memorias, 1-10.

Vega, F.J., Charbonnier, S., Gómez-Pérez, L.E., Coutiño, M.A., Carbot-Chanona, G., de Araújo Távora, V., de Lourdes Serrano-Sánchez, M., Téodori, D. \& Hernández-Monzón, O. (2018) Review and additions to the Maastrichtian (Late Cretaceous) crustacea from Chiapas, Mexico. Journal of South American Earth Sciences, 85, 325-344.

https://doi.org/10.1016/j.jsames.2018.05.017 